\title{
Male circumcision and prostate cancer: A geographical analysis, meta-analysis, and cost analysis
}

Robert S. Van Howe, MD, MS, FAAP

Department of Pediatrics and Human Development, Michigan State University College of Human Medicine, Grand Rapids, MI, United States

Acknowledgement: The author would like to thank Gregory Boyle, $\mathrm{PhD}$, for encouraging him to complete this project and for his editorial suggestions.

Cite as: Can Urol Assoc J 2020 February 4; Epub ahead of print. http://dx.doi.org/10.5489/cuaj.6126

Published online February 4, 2020

$* * *$

\section{Abstract}

Introduction: Attempts to find an association between male circumcision and prostate cancer risk have produced inconsistent results.

Methods: Age-standardized prostate cancer incidence, life-expectancy, geographical region, and circumcision prevalence from 188 countries were compared using linear regression analysis. Following a systematic literature review, a meta-analysis was performed on studies meeting inclusion criteria with evaluations of between-study heterogeneity and publication bias. A cost analysis (discounted at 3\% and 5\% per annum) was performed using the meta-analysis's summary effect and upper confidence interval (CI).

Results: Univariate analysis revealed a trend for a positive association between country-level age-standardized prostate cancer incidence (per 100000 person-years) and circumcision prevalence $(\beta=0.0887 ; 95 \%$ CI $-0.0560,+0.233$ ) while multivariate analysis found a significant positive association $(\beta=0.215 ; 95 \%$ CI $0.114,0.316)$. Twelve studies were included in metaanalysis. The random-effects summary odds ratio was 1.09 (95\% CI 0.95, 1.23; between-study heterogeneity $\chi^{2}{ }_{12}=22.92 ; \mathrm{p}=0.029 ; \mathrm{I}^{2}=43.3 \%$ ). There was no evidence of publication bias. Costanalysis found infant circumcision was prohibitively costly, returning only between $1.4 \varnothing$ and $12.5 \notin$ for each dollar expended.

Conclusions: Circumcision may be a positive risk factor on geographical analysis, but not in case-controlled studies. Circumcision is not economically feasible for preventing prostate cancer. 


\section{Introduction}

Prostate cancer is a common malignancy in elderly men, the primary cause of which is not clearly known. Dietary habits, behavioral factors, and racial identification have been identified as potential risk factors. ${ }^{1}$ The notion that circumcision may reduce the risk of prostate cancer originated in 1942 with Abraham Ravich, who repeated these same "finding" over the next 25 years. ${ }^{2-4}$ Since then a handful of studies have evaluated the contribution of circumcision status to the risk of prostate cancer with mixed results. In their 1989, 1999, and 2012 policy statements on neonatal circumcision, the various circumcision Task Forces of the American Academy of Pediatrics (AAP) fail to mention prostate cancer. ${ }^{5-7}$ In its 2018 guidelines on neonatal circumcision, the Canadian Urological Association noted "a borderline association on univariate analysis between circumcision and prostate cancer risk." Attention to this issue has generated an informal geographic analyses of the incidence of prostate cancer, ${ }^{9,10}$ a formal geographical analysis of prostate cancer mortality, ${ }^{11}$ two concurrent meta-analyses, ${ }^{12,13}$ and an informal cost analyses. ${ }^{14}$ Subsequently more epidemiological data have become available. This report will update and more thorough analyze of any association between male circumcision and prostate cancer.

\section{Methods}

\section{Geographic analysis}

Country level epidemiological data of the age-standardized incidence of prostate cancer was obtained from the International Agency for Research on Cancer (IARC) 2012 GLOBOCAN report. ${ }^{15}$ Circumcision prevalence by country were procured from previously published estimates. ${ }^{16}$ World Health Organization 2016 estimates of life-expectancy by country were used. ${ }^{17}$ The weight assigned for population for each country was calculated by taking the number of cases reported in the IARC report for that country and dividing it by the age-standardized incidence (per 100000 person-years). Univariate and multivariate linear regression models were developed using age-standardized incidence (per 100000 person-years) as the dependent variable and circumcision prevalence, male life-expectancy, and the region in which the country presides (Middle East, sub-Saharan Africa, Europe, Asia, North America, South America, Australia/New Zealand, Central America/Caribbean, and Pacific Islands) as independent variables. (See Supplemental Table) Analysis of residuals was performed.

\section{Meta-analysis}

Following the recommendations of Stroup et al. for the meta-analysis of observational studies, ${ }^{18}$ studies were identified in a MEDLINE search using the search terms "circumcision" and "prostate cancer" on December 16, 2018. Additional studies were identified using the bibliographies of studies identified in the search and by surveying researchers in the field. Inclusion criteria included randomized clinical trials, cohort studies, cross-sectional studies, and 
case-controlled studies. Jewish men have a significantly lower prevalence of prostate cancer than circumcised Gentiles (odds ratio $(\mathrm{OR})=3.23,95 \%$ confidence interval $(\mathrm{CI}): 1.56,6.69){ }^{19}$ indicating the potential for confounding. Consequently, comparisons between Jewish men and other populations were excluded.

When available, the primary analysis was performed using raw data. In one case, the raw data were obtained by contacting the study's lead author. ${ }^{20}$ If within a study a clear distinction was evident between strata, each stratum was included separately.

Dersimonian and Laird random-effects summary results and between-study heterogeneity were calculated using the Mantel-Haenszel method. ${ }^{21}$ To test for potential outliers, the dataset from each publication was individually excluded from the analysis to measure the impact measures of between-study heterogeneity. The exclusion of a study would be justified by a statistically significant reduction of the between-study heterogeneity $\chi^{2}$. Sensitivity analysis was performed with each of these studies excluded. The number of studies and the percentage of participants excluded to reach $\mathrm{I}^{2}$ thresholds of $50 \%$ and $25 \%$ were estimated. ${ }^{22}$ Meta-regression of study characteristics was performed. ${ }^{23}$

Publication bias was assessed using funnel graphs and linear regression analysis, ${ }^{24}$ funnel plot regression, ${ }^{25}$ and an adjusted rank correlation test. ${ }^{26}$ Any adjustments for publication bias were performed using the "trim and fill" method. ${ }^{27}$ Linear regression analyses and assessment of publication bias and meta-regression analyses were performed using SAS version 8.02 (SAS Institute, Cary, North Carolina). All reported P-values are two-sided.

\section{Cost analysis}

A hypothetical model of one million men was constructed using the age-standardize incidence of prostate cancer (96.6 per 100,000 person-years) and the life-expectancy (78.3) in Finland going from a circumcision rate of zero to $100 \%$. The cost of an infant circumcision has been estimated to be $\$ 285 .^{28}$ The average cost of treating prostate cancer was assumed to be $\$ 20,000$. The average age of detection of prostate cancer and initiation of treatment is 70 years. The attributable proportion was calculated ((summary odds ratio - 1)/summary odds ratio) to determine the number of cases of prostate cancer averted through circumcision. The summary random-effects odds ratio and upper 95\% confidence interval from the meta-analysis were both put into models that employed 3\% and 5\% per annum discount rates.

\section{Results}

\section{Geographical analysis}

The results of the univariate and multivariate linear regression are seen in Table 1. These results indicate that circumcision prevalence is positively associated with the incidence of prostate cancer. A significant positive correlation was found between life-expectancy and prostate cancer incidence $(\beta=2.46,95 \% \mathrm{CI}: 1.71,3.21, \mathrm{t}=6.44, \mathrm{p}<0.0001)$, as well as a negative correlation 
between life-expectancy and circumcision prevalence $(\beta=-0.0512,95 \% \mathrm{CI}:-0.0766,-0.0258, \mathrm{t}=$ $3.98, \mathrm{p}=0.0001$ ). This indicates that men in countries with a higher circumcision prevalence did not live as long. This association did not persist when adjusted for the various regions of the world $(\beta=-0.0249,95 \% \mathrm{CI}:-0.0594,+0.00441, \mathrm{t}=-1.70, \mathrm{p}=0.09)$. There was no significant interaction (effect modification) between circumcision prevalence and life-expectancy $(p=0.84)$. Region of the world was significantly associated with life-expectancy, circumcision prevalence, and the incidence of prostate cancer (data not shown). An examination of the residuals found they were normally distributed with Mexico, the United States, China, and India as significant outliers ( $\left.\mathrm{r}_{\text {student }}>4\right)$.

\section{Meta-analysis}

Fifty-one publications were identified using the MEDLINE search. Of these, only seven met the inclusion criteria. ${ }^{20,29-34}$ An additional three studies were identified using bibliographies. ${ }^{35-37} \mathrm{~A}$ further two studies were identified through contacting researchers in the field. ${ }^{19,38}$ All studies identified were case-controlled studies whose characteristics are listed in Table 2.

The results of the meta-analysis are shown in Table 3. the random effects summary effect odds ratio was 1.09 (95\%CI: 0.95, 1.23). There was significant between-study heterogeneity $\left(\chi^{2}{ }_{12}=22.92, \mathrm{p}=0.03, \mathrm{I}^{2}=43.3 \%\right)$.

Two studies were identified as a potential outliers. ${ }^{30,36}$ When either of these studies in removed, the $\mathrm{I}^{2}$ drops below $25 \%$. When both these study was removed from the meta-analysis the $\mathrm{I}^{2}$ is zero and the summary effect odds ratio was $1.10(95 \% \mathrm{CI}: 1.06,1.16)$.

For each study, the natural logarithm of the odds ratio was plotted in the x-axis against the inverse of variance in the y-axis in Figure 1. This funnel plot appears symmetrical. There is no evidence of publication bias in Begg and Mazudar's adjusted rand correlation test (original: $\mathrm{p}=0.81$, alternate: $\mathrm{p}=0.58$ ), or the linear aggression regression analysis of Egger and associates (unweighted: $\mathrm{p}=0.82$; weighted $\mathrm{p}=0.93$ ) or Macaskill, Walter, and Irving (unweighted: $\mathrm{p}=0.99$; weighted: $\mathrm{p}=0.67)$. A “trim and fill" evaluation found no evidence of a missing study.

Meta-regression evaluated the impact of publication after the introduction of screening with the prostate-specific antigen (PSA) test and found no statistically significant difference $(\mathrm{t}=0.42, \mathrm{p}=0.68)$. There was no statistically significant difference between studies that were population-based as opposed to institution-based $(\mathrm{t}=0.89, \mathrm{p}=0.39)$.

\section{Cost analysis}

Based on the meta-analysis, with the summary random-effects odds ratio estimated at 1.09 and the upper $95 \%$ confidence limit at 1.23 , the attributable proportion would range from $8.26 \%$ to $18.70 \%$. In the population of one million over 78.3 years, we would expect 75,638 men to develop prostate cancer. Going from a circumcision rate of zero to $100 \%$ would theoretically prevent between 6,245 to 14,141 cases of prostate cancer, with a savings of between $\$ 125$ and 
$\$ 283$ million in treatment costs. The cost of circumcising a million boys would be $\$ 285$ million. The opportunity costs of expending $\$ 285$ million on a neonate would be $\$ 2.26$ billion ( $3 \%$ discount) to $\$ 8.67$ billon (5\% discount) at 70 years of age. For every dollar spent on circumcision one would expect to save $5.5 \varnothing$ to $12.5 \phi$ ( $3 \%$ discount) or $1.4 \varnothing$ to $3.3 \phi$ (5\% discount). To be less costly either a circumcision need to cost less than $\$ 15.78$ to $\$ 35.72$. (3\% discount) or $\$ 4.11$ to $\$ 9.30$ (5\% discount) or the average cost of treating a case of prostate cancer would need to exceed $\$ 159,819$ to $\$ 361,890$ (3\% discount) or $\$ 613,111$ to $\$ 1,388,311$ (5\% discount).

\section{Discussion}

The geographical analysis discovered a positive association between circumcision prevalence and the incidence of prostate cancer. The meta-analysis of 12 studies failed to document a significant association between male circumcision and prostate cancer incidence. The costanalysis found infant circumcision to be a prohibitively costly option to avert prostate cancer.

This is fourth published geographical analyses of county-level data of prostate incidence and circumcision prevalence. Morris and colleagues reported an analysis attributed to Waskett of 51 countries that documented a significant negative association between circumcision prevalence and prostate cancer incidence $(\mathrm{p}=0.02){ }^{9}$ This analysis was subsequently expanded to 181 countries with similar results $(\mathrm{p}<0.0001) .{ }^{10}$ The source of the circumcision prevalence data and the methods of calculation were not provided in either of these reports. An analysis of the current dataset that does not weigh each country's datapoint for population size was able to replicate their results $(\beta=-0.311,95 \% \mathrm{CI}:-0.205,-0.418, \mathrm{t}=-5.75, \mathrm{p}<0.0001)$, but such an unweighted model is not informative as such an analysis attributes Comoros as much influence on the final estimate as China.

Wachtel, Yang, and Morris published a geographical analysis looking at the prevalence of male circumcision (stratified into rates less than $20 \%, 21 \%$ to $80 \%$, and more than $80 \%$ ) on prostate cancer mortality. ${ }^{11}$ Although their specific methodology is not stated, it appears that they used a Poisson regression model adjusting for gross per-capita national income, religion, and WHO region. It is unclear from their report how the calculations were made, or what the results mean. No account is given for life-expectancy. More importantly, the results of the analysis do no support the conclusions reached by the authors. ${ }^{39}$ The report focused only on mortality, which may be impacted by a number of factors, including life-expectancy.

Two previous meta-analyses have been published. A 2015 meta-analysis of seven studies found a non-significant reduction of prostate cancer risk in circumcised men $(O R=0.88, p=0.19$, $\left.\mathrm{I}^{2}=65 \%\right) .{ }^{12}$ A 2016 meta-analysis of six case-control studies found a significantly lower prevalence of circumcision in prostate cancer patients compared with controls $(\mathrm{OR}=0.90$, 95\%CI: $0.82,0.98){ }^{13}$

While one of these analyses suggested difference before and after the introduction of prostate specific antigen (PSA) testing, the meta-regression analysis in the current study failed to 
find a difference. The 2015 meta-analysis failed to include one study, ${ }^{32}$ and the 2016 failed to include three studies ${ }^{29,30,32}$ that should have been identified in even the most cursory PUBMED search.

Because prostate cancer has been associated with sexually transmitted infections (with the speculation that these infections ascend to the prostate, resulting in local irritation and malignancy), and because sexually transmitted infection have been purported to be more common in intact men, circumcision advocates have speculated that circumcision reduces the risk of prostate cancer. $9,11,14$

This theory, which follows in the footsteps the theory that smegma causes prostate cancer, ${ }^{4,40}$ has several deficiencies. First, prostate cancer usually arises in the posterior lobe, which is the furthest away from the urethra. ${ }^{19}$ If the ascending infection theory were true, one would expect the portion of the prostate cancer closest to the urethra to host more carcinomas.

Second, the irritation theory is not well-supported by the inconsistent empirical evidence. ${ }^{41-}$ 45 A 2014 meta-analysis found men with a history of any sexually transmitted infection at a significantly greater risk for prostate cancer. When broken down into specific infections, a history of gonorrhea was associated with a significant increased risk of prostate cancer, but no significant differences were seen for Treponema pallidum, Chlamydia trachomatis, Trichomonas vaginalis, Ureaplasma urealyticum, Mycoplasma hominis, herpes simplex virus type 1 or type 2, human herpes virus 8 , or cytomegalovirus. ${ }^{46}$ Circumcision has no association with a history of gonorrhea. $^{47}$

While one study reported an association between prostate cancer and a positive serology for HPV16 and HPV 18 but not other strains of HPV, ${ }^{45}$ the same group of researchers subsequently failed to confirm any association. ${ }^{48}$ Other studies have been unable to detect HPV DNA in human prostatic malignancies. ${ }^{49,50}$

Morris and colleagues ${ }^{9}$ emphasized the role of Moloney murine leukemia virus in prostatic cancer in patients with a genetic variant of HPC1 that encodes RNaseL. ${ }^{51,52}$ Hohn and colleagues were unable to replicate this findings. ${ }^{53}$ Lee and colleagues subsequently found that the virus, which is not a naturally acquired human infection, was a contaminant. ${ }^{54}$ The publications purporting this theory ${ }^{51,52}$ were in turn retracted. ${ }^{55,56}$

It noteworthy that Wright, Lin, and Stanford "believe there is strong biological plausibility for a relation between circumcision and the risk of [prostate cancer]," yet their own study failed to confirm this $(\mathrm{OR}=1.05,95 \% \mathrm{CI}: 0.87,1.27){ }^{33}$

Third, the speculative infection theory does not explain the increased prostate cancer mortality among Roman Catholic priests. ${ }^{41}$

Fourth, men infected with HIV are at greater risk for other sexually transmitted infections and at greater risk for infection-related cancers, yet large-scale prospective studies of the risk of prostate cancer in HIV-infected men have found that these men have significantly lower 
incidence of prostate cancer than the general population. ${ }^{57}$ If prostate cancer risk was related to infection, we would expect the incidence to be greater in HIV-infected men. ${ }^{58}$

Finally, the assertion that intact men are at greater risk of sexually transmitted infections is debatable. Urethritis is more common in circumcised men, HPV infects intact and circumcised men equally, and the studies on Trichamonas vaginalis are inconsistent. ${ }^{46}$ Furthermore, if circumcision was effective in lowering prostate cancer, one would have expected a drop in the incidence of prostate cancer as the circumcision rate of men entering their seventh and eight decade of life increased in the United States. Instead between 1987 and 1992 the agestandardized incidence rate of prostate cancer increased from 102.9 per 100,000 person-years to 189.4 per 100,000 person-years. ${ }^{59}$

Weaknesses in these analyses include reliance on estimates, rather than actual data collection, to determine circumcision prevalence in each country. These estimates were determined by individuals with a strong history of circumcision advocacy. One estimate stands out: the $14 \%$ circumcision prevalence in China. Because of China's large population, the linear regression was recalculated using a circumcision prevalence of $2.7 \%$. This change slightly altered the overall finding of the geographical analyses (univariate: $\beta=0.136,95 \% \mathrm{CI}$ : 0.000754 , 0.274, $\mathrm{t}=1.96, \mathrm{p}=0.0513$; multivariate: $\beta=0.236,95 \% \mathrm{CI}: 0.142,0.330, \mathrm{t}=4.96, \mathrm{p}<0.0001$ ).

Population-sized weighted country-specific datapoints avoids allowing small countries to have the same influence on the estimate as larger countries. The caveat with weighting each datapoint is that the quality of the data collected in each country may vary. If poor quality data is collected in a populous country, this weakness may be amplified because of the country's size. Similarly, well-collected data from a smaller country would be not receive the weight it may deserve. This concern also applies to studies included in a meta-analysis: the weight given to a study in a meta-analysis is based on variance, which is based on the number of participants in a study not on the quality of the data collection.

Average life-expectancy was included in the regression model because prostate cancer incidence had a significant positive association and circumcision prevalence had a significant negative association with life-expectancy. If a country has a low life-expectancy, fewer men will reach an age at which prostate cancer presents itself. This phenomenon should be captured by using calculated age-standardized rates. The positive association between age-standardized rates and life-expectance indicates that age may have either have a multiplier effect on prostate cancer incidence or it may be marker for favorable socio-economic conditions. Life expectancy remained a significant factor on both bivariate and multivariate analyses.

The studies included in the meta-analysis had a number of methodological weaknesses. Nearly all relied on patient-report to determine circumcision status. Some studies used patients with other types of medical conditions as the control group, ${ }^{19,31}$ introducing the potential for selection bias. ${ }^{58}$ 
For the future, studies that determine circumcision status based on physical examination are needed. We also need national estimates of circumcision prevalence that are not based merely on speculation.

The link between circumcision status and the risk of prostate cancer is tenuous at best. A 2016 review of prostate cancer in The Lancet, fails mention circumcision. ${ }^{60}$ It was ignored by the American Academy of Pediatrics in 1989, 1999, and 2012, ${ }^{5-7}$ but was resurrected by the Centers for Disease Control and Prevention in $2014^{61}$ Raising the possibility that circumcison may reduce the risk of prostate cancer is attractive to circumcision advocates because prostate cancer is a relatively common cancer in men. Demonstrating even a limited association between circumcision and prostate cancer risk can result in substantial numbers across a population. When asked why he robbed banks, Willie Sutton quipped, "Because that's where the money is." Given the vested interests and the potential financial payout, circumcision proponents are unlikely to back away from using prostate cancer as an excuse to perpetuate the practice. 


\section{References}

1. Kheirandish $\mathrm{P}$, Chinegwundoh $\mathrm{F}$. Ethnic differences in prostate cancer. $\mathrm{Br} \mathrm{J}$ Cancer 2011;105:481-5.

2. Ravich A. The relationship of circumcision to cancer of the prostate. J Urol 1942;48:2989.

3. Ravich A, Ravich RA. Prophylaxis of cancer of the prostate, penis and cervix by circumcision. N Y J Med 1951;51:1519-20.

4. Ravich A. Venereal origin and prevention of genito-urinary cancers. J Nat Med Assoc 1967;59:95-9.

5. American Academy of Pediatrics:Report of the Task Force on Circumcision. Pediatrics 1989;84:388-91.

6. American Academy of Pediatrics Task Force on Circumcision. Circumcision policy statement. Pediatrics 1999;103:686-93.

7. Task Force on Circumcision. Male circumcision. Pediatrics 2012;130:e756-5.

8. Dave S, Afshar K, Braga LH, et al. Canadian Urological Association guideline on the care of the normal foreskin and neonatal circumcision in Canadian infants (full version). Can Urol Assoc J 2018;12:E76-99.

9. Morris BJ, Gray RH, Castellsague X, et al. The strong protective effect of circumcision against cancer of the penis. Adv Urol 2011;2011:812368.

10. Morris BJ, Waskett JH. Circumcision reduces prostate cancer risk. Asian J Androl 2012;14:661-2.

11. Wachtel MS, Yang S, Morris BJ. Countries with high circumcision prevalence have lower prostate cancer mortality. Asian J Androl 2015;18:39.

12. Pabalan N, Singian E, Jarjanazi H, et al. Association of male circumcision with risk of prostate cancer: a meta-analysis. Prostate Cancer Prostatic Dis 2015;18:352-7.

13. Li YD, Teng Y, Dai Y, et al. The association of circumcision and prostate cancer:a metaanalysis. Asian Pac J Cancer Prev 2016;17:3823-7.

14. Morris BJ, Waskett J, Bailis SA. Case number and the financial impact of circumcision in reducing prostate cancer. BJU Int 2007;100:5-6.

15. International Agency for Research on Cancer. GLOBOCAN 2012: Estimated Cancer Incidence, Mortality and Prevalence Worldwide in 2012. Accessed September 4, 2017. http://globocan.iarc.fr/Pages/fact sheets population.aspx

16. Morris BJ, Wamai RG, Henebeng EB, et al. Estimation of country-specific and global prevalence of male circumcision. Popul Health Metrics 2016;14:11.

17. World Health Statistics 2016: Monitoring health for the SDBs Annex B: tables of health statistics by country, WHO region and globally. World Health Organization, 2016. Accessed September 4, 2017. http://www.who.int/gho/publications/world health_statistics/2016/Annex_B/en/

18. Stroup DF, Berlin JA, Morton SC, et al. Meta-analysis of observational studies in epidemiology: a proposal for reporting. JAMA 2000;283:2008-12.

19. Kaplan GW, O'Connor VJ Jr. The incidence of carcinoma of the prostate in Jews and gentiles. JAMA 1966;196:123-4. 
20. Nair-Shalliker V, Yap S, Nunez C, et al. Adult body size, sexual history and adolescent sexual development, may predict risk of developing prostate cancer: Results from the New South Wales Cancer Lifestyle and Evaluation of Risk Study (CLEAR). Int J Cancer 2017; 140:565-574.

21. Petitti DB. Meta-Analysis, Decision Analysis, and Cost-Effectiveness Analysis: Methods for Quantitative Synthesis in Medicine. 2nd edition. New York, NY: Oxford University Press;2000.

22. Patsopoulos NA, Evangelou E, Ioannidis JPA. Sensitivity of between-study heterogeneity in meta-analysis: proposed metrics and empirical evaluation. Int J Epidemiol 2008;37:1148-57.

23. van Houwelingen HC, Arends LR, Stijnen T. Advanced methods in meta-analysis: multivariate approach and meta-regression. Stat Med 2002;21:589-624.

24. Egger M, Davey Smith G, Schneider M, et al. Bias in meta-analysis detected by a simple, graphical test. Br Med J 1997;315:629-34.

25. Macaskill P, Walter SD, Irwig L. A comparison of methods to detect publication bias in meta-analysis. Statist Med 2001;20:641-54.

26. Begg CB, Mazumdar M. Operating characteristics of a rank correlation test for publication bias. Biometrics 1994;50:1088-101.

27. Duvall S, Tweedie R. Trim and fill: a simple funnel-plot-based method of testing and adjusting for publication bias in meta-analysis. Biometrics 2000;56:455-63.

28. Hart-Cooper GD, Tao G, Stock JA, et al. Circumcision of privately insured males aged 0 to 18 years in the United States. Pediatrics 2014;134:950-6.

29. Wynder EL, Mabuchi K, Whitmore WF Jr. Epidemiology of cancer of the prostate. Cancer 1971;28:344-60.

30. Ross RK, Shimizu H, Paganini-Hill A, et al. Case-control studies of prostate cancer in blacks and whites in southern California. J Natl Cancer Inst 1987;78:869-74.

31. Ewings P, Bowie C. A case control study of cancer of the prostate in Somerset and east Devon. Br J Cancer 1996;74:661-6.

32. Madsen BS, van den Brule AJC, Jensen HL, et al. Risk factors for squamous cell carcinoma of the penis - population-based case-control study in Denmark. Cancer Epidemiol Biomarkers Prev 2008;17:2683-91.

33. Wright JL, Lin DW, Stanford JL. Circumcision and the risk of prostate cancer. Cancer 2012;118:4437-43.

34. Spence AR, Rousseau MC, Karakiewicz PI, Parent MÉ. Circumcision and prostate cancer: a population-based case-control study in Montréal, Canada. BJU Int 2014;114:E90-8.

35. Mandel JS, Schuman LM. Sexual factors and prostatic cancer: results from a case-control study. J Gerontol 1987;42:259-64.

36. Newell GR, Fueger JJ, Spitz MR, et al. A casecontrol study of prostate cancer. Am J Epidemiol 1989;130:395-8.

37. Rosenblatt KA, Wicklund KG, Stanford JL. Sexual factors and the risk of prostate cancer. Am J Epidemiol 2001;153;1152-8. 
38. Rotkin ID. Studies in the epidemiology of prostatic cancer: expanded sampling. Cancer Treat Rep 1977;61:173-80.

39. Kupferschmid C. Commentary on "Countries with high circumcision prevalence have lower prostate cancer mortality". Asian J Androl 2016;18:949.

40. Ravich A. Role of circumcision in cancer prevention. Acta Urol Jap 1965;11:79-86.

41. Ross RK, Paganini-Hill A, Henderson BE. The etiology of prostate cancer: what does the epidemiology suggest? Prostate 1983;4:333-44.

42. Hayes RB, Pottern LM, Strickler H, et al. Sexual behaviour, STDs and risks for prostate cancer. Br J Cancer 2000;82:718-25.

43. Oliver JC, Oliver RT, Ballard RC. Influence of circumcision and sexual behaviour on PSA levels in patients attending a sexually transmitted disease (STD) clinic. Prostate Cancer Prostatic Dis 2001;4:228-31.

44. Fernández L, Galán Y, Jiménez R, et al. Sexual behaviour, history of sexually transmitted diseases, and the risk of prostate cancer: a case-control study in Cuba. Int J Epidemiol 2005;34:193-7.

45. Dillner J, Knekt P, Boman J, et al. Sero-epidemiological association between humanpapillomavirus infection and risk of prostate cancer. Int J Cancer 1998;75:564-7.

46. Caini S, Gandini S, Dudas M, et al. Sexually transmitted infections and prostate cancer risk: a systematic review and meta-analysis. Cancer Epidemiol 2014;38:329-38.

47. Van Howe RS. Sexually transmitted infections and male circumcision: a systematic review and meta-analysis. ISRN Urol 2013:109846.

48. Adami H-O, Kuper H, Andersson S-O, et al. Prostate cancer risk and serologic evidence of human papilloma virus infection: a population-based case-control study. Cancer Epidemiol Biomarkers Prev 2003;12:872-5.

49. Balis V, Sourvinos G, Soulitzis N, et al. Prevalence of BK virus and human papillomavirus in human prostate cancer. Int J Biol Markers 2007;22:245-51.

50. Gazzaz FS, Mosli HA. Lack of detection of human papillomavirus infection by hybridization test in prostatic biopsies. Saudi Med J 2009;30:633-7.

51. Urisman A, Molinaro RJ, Fischer N, et al. Identification of a novel Gammaretrovirus in prostate tumors of patients homozygous for R462Q RNASEL variant. PLoS Pathog 2006;2:e25.

52. Schlaberg R, Choe DJ, Brown KR, et al. XMRV is present in malignant prostatic epithelium and is associated with prostate cancer, especially high-grade tumors. Proc Natl Acad Sci U S A 2009;106:16351-6.

53. Hohn O, Krause H, Barbarotto P, et al. Lack of evidence for xenotropic murine leukemia virus-related virus(XMRV) in German prostate cancer patients. Retrovirology 2009;6:92.

54. Lee D, Gupta JD, Gaughan C, et al. In-depth investigation of archival and prospectively collected samples reveals no evidence for XMRV infection in prostate cancer. PLoS One 2012;7:e44954.

55. Retraction. Identification of a novel gammaretrovirus in prostate tumors of patients homozygous for R462Q RNASEL variant. PLoS Pathog 2012 Sep;8(9). 
56. Retraction for Schlaberg et al., XMRV is present in malignant prostatic epithelium and is associated with prostate cancer, especially high-grade tumors. Proc Natl Acad Sci U S A 2014;111:12270.

57. Grulich AE, van Leeuwen MT, Falster MO, et al. Incidence of cancers in people with HIV/AIDS compared with immunosuppressed transplant recipients: a meta-analysis. Lancet 2007;370:59-67.

58. Grulich AE, Vajdic CM. Circumcision unlikely to be associated with prostate cancer risk. Cancer 2013;119:245.

59. Wingo PA, Landis S, Ries LAG. An adjustment to the 1997 estimate for new prostate cancer cases. CA Cancer J Clin 1997;47:239-42.

60. Attard G, Parker C, Eeles RA, et al. Prostate cancer. Lancet 2016;387:70-82.

61. Centers for Disease Control and Prevention, Division of HIV/AIDS Prevention, National Center for HIV/AIDS, Viral Hepatitis, STD, and TB Prevention. Background, methods, and synthesis of scientific information used to inform "Information for providers to share male patients and parents regarding male circumcision and the prevention of HIV infection, sexually transmitted infections, and other health outcomes". Atlanta, GA: Centers for Disease Control and Prevention; 2018. 


\section{Figures and Tables}

Fig. 1. Funnel plot of studies assessing the association between male circumcision and prostate cancer with the natural logarithm of the odds ratio on the $\mathrm{x}$-axis and the inverse of variance on the y-axis.

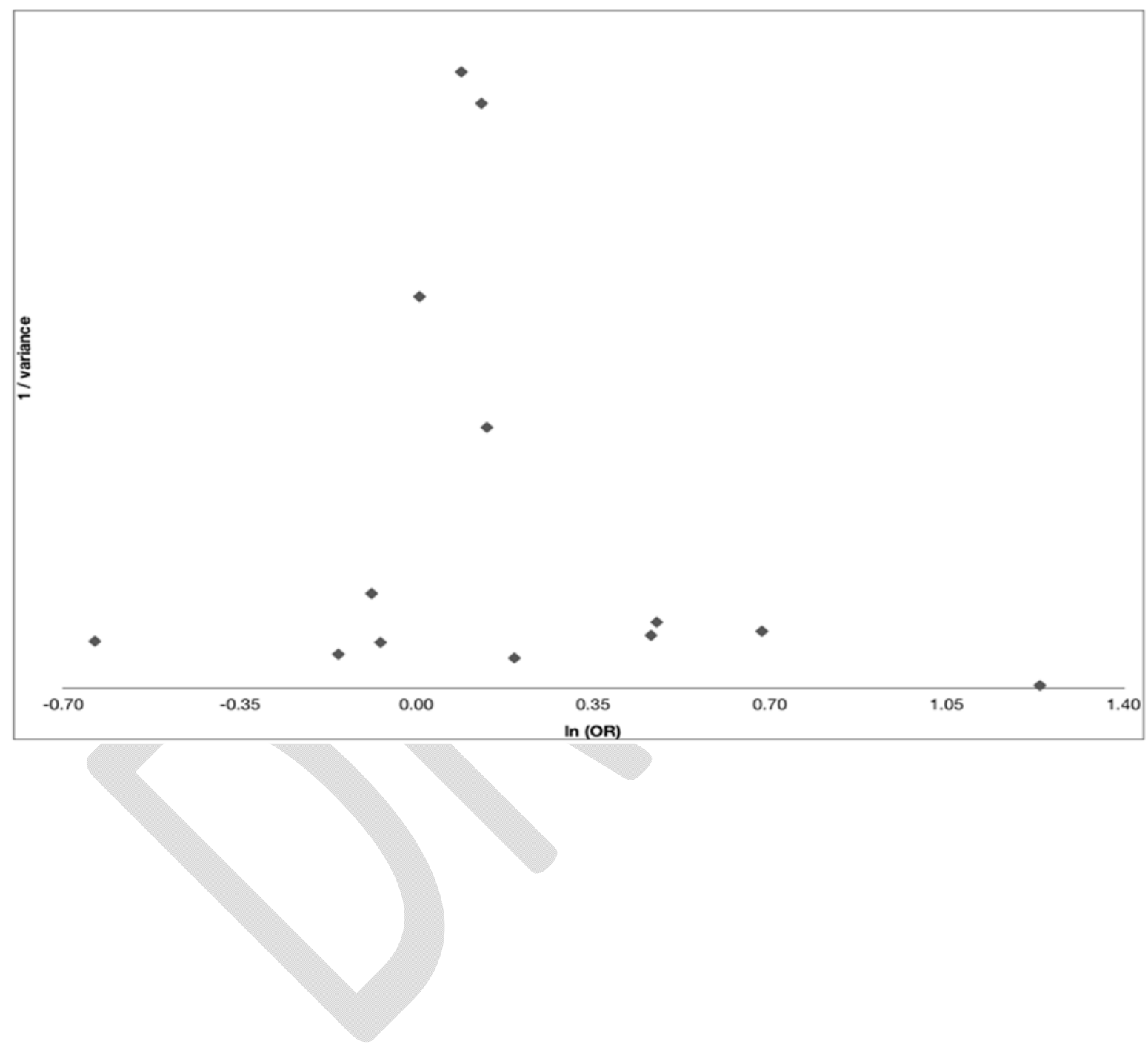


Table 1. Geographical analysis of 188 countries of the country-level age-standardized incidence (per 100000 person-years) of prostate cancer as a function of country-level male circumcision prevalence using linear regression analysis

\begin{tabular}{|c|c|c|c|c|}
\hline Factor & Beta $(\beta)$ & $\begin{array}{l}95 \% \text { confidence } \\
\text { interval }\end{array}$ & t-value & $\mathbf{p}$ \\
\hline \multicolumn{5}{|l|}{ Univariate analysis } \\
\hline Circumcision prevalence & 0.0887 & -0.0560 to +0.233 & 1.21 & 0.23 \\
\hline \multicolumn{5}{|l|}{ Bivariate analyses } \\
\hline Circumcision prevalence & 0.236 & 0.101 to 0.370 & 3.47 & 0.0007 \\
\hline Life expectancy & 2.85 & 2.09 to 3.61 & 7.37 & $<0.0001$ \\
\hline Circumcision prevalence & 0.153 & 0.0350 to 0.272 & 2.56 & 0.0114 \\
\hline Region & $\mathrm{F}=55.07$ & & 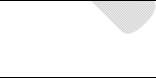 & $<0.0001$ \\
\hline \multicolumn{5}{|l|}{ Multivariate analysis } \\
\hline Circumcision prevalence & 0.215 & 0.114 to 0.316 & 4.20 & $<0.0001$ \\
\hline Life expectancy & 2.13 & 1.65 to 2.62 & 8.65 & $<0.0001$ \\
\hline Region & $\mathrm{F}=60.78$ & & & $<0.0001$ \\
\hline
\end{tabular}


Table 2. Characteristics of studies assessing the association between male circumcision and prostate cancer

\begin{tabular}{|c|c|c|c|c|}
\hline First author & Location & Patient source & Controls & $\begin{array}{c}\text { Data collection } \\
\text { method }\end{array}$ \\
\hline Kaplan 1966 & Chicago & Hospital & $\mathrm{BPH}$ & Chart review \\
\hline Wynder 1971 & New York & Hospital & No prostatic disease & $\begin{array}{l}\text { Person-to-person } \\
\text { interview }\end{array}$ \\
\hline Rotkin 1977 & $\begin{array}{l}\text { California, } \\
\text { Chicago }\end{array}$ & Hospital & Matched pairs & $\begin{array}{c}\text { Physical } \\
\text { examination }\end{array}$ \\
\hline Ross 1987 & $\begin{array}{l}\text { California, } \\
\text { Chicago }\end{array}$ & Population & Neighborhood & $\begin{array}{l}\text { Person-to-person } \\
\text { interview }\end{array}$ \\
\hline Mandel 1987 & $\begin{array}{l}\text { Minneapolis/ } \\
\text { Saint Paul }\end{array}$ & $\begin{array}{l}\text { Hospital/ } \\
\text { population }\end{array}$ & $\begin{array}{l}\text { Matched for age, } \\
\text { sex \& race }\end{array}$ & $\begin{array}{l}\text { Person-to-person } \\
\text { interview }\end{array}$ \\
\hline Newell 1989 & Texas & Hospital & $\begin{array}{c}\text { Treatment center } \\
\text { and time, } 2 \text { controls } \\
\text { per case }\end{array}$ & Questionnaire \\
\hline Ewings 1996 & $\begin{array}{l}\text { Somerset and } \\
\text { east Devon }\end{array}$ & Hospital & $\begin{array}{l}\text { One control with } \\
\text { BPH, one control } \\
\text { with non-urological } \\
\text { condition }\end{array}$ & $\begin{array}{l}\text { Person-to-person } \\
\text { interview }\end{array}$ \\
\hline Rosenblatt 2001 & $\begin{array}{l}\text { Kings County } \\
\text { Washington }\end{array}$ & Population & $\begin{array}{l}\text { Random-digit } \\
\text { dialing, age- } \\
\text { matched }\end{array}$ & $\begin{array}{l}\text { Person-to-person } \\
\text { interview }\end{array}$ \\
\hline Madsen 2008 & Denmark & Population & $\begin{array}{l}\text { Prostate cancer and } \\
\text { population controls }\end{array}$ & $\begin{array}{l}\text { Telephone } \\
\text { interview }\end{array}$ \\
\hline Wright 2012 & Washington State & Population & $\begin{array}{l}\text { Random-digit } \\
\text { dialing, matched by } \\
\text { 5-year age groups }\end{array}$ & $\begin{array}{l}\text { Person-to-person } \\
\text { interview }\end{array}$ \\
\hline Spence 2014 & Montreal & Population & $\begin{array}{l}\text { Electoral list, } \\
\text { matched by age }\end{array}$ & $\begin{array}{l}\text { Person-to-person } \\
\text { interview }\end{array}$ \\
\hline $\begin{array}{l}\text { Nair-Shalliker } \\
2017\end{array}$ & $\begin{array}{l}\text { New South } \\
\text { Wales }\end{array}$ & Population & Cancer-free & Questionnaire \\
\hline
\end{tabular}

$\mathrm{BPH}$ : benign prostatic hypertrophy. 
Table 3. Meta-analysis of studies assessing the association between male circumcision and prostate cancer

\begin{tabular}{|l|c|c|c|c|c|c|}
\hline Study & $\begin{array}{c}\text { Circumcised } \\
\text { positive }\end{array}$ & $\begin{array}{c}\text { Circumcised } \\
\text { negative }\end{array}$ & $\begin{array}{c}\text { Intact } \\
\text { positive }\end{array}$ & $\begin{array}{c}\text { Intact } \\
\text { negative }\end{array}$ & OR & 95\% CI \\
\hline Kaplan & 34 & 90 & 19 & 61 & 1.21 & $0.63,2.32$ \\
\hline Wynder & 143 & 121 & 29 & 21 & 0.86 & $0.46,1.58$ \\
\hline Rotkin & 52 & 54 & 59 & 57 & 0.93 & $0.55,1.58$ \\
\hline Ross - white & 81 & 57 & 61 & 85 & 1.98 & $1.23,3.18$ \\
\hline Ross - black & 99 & 84 & 43 & 58 & 1.59 & $0.97,2.59$ \\
\hline Mandel & 124 & 137 & 102 & 103 & 0.91 & $0.63,1.32$ \\
\hline Newell & 50 & 114 & 44 & 53 & 0.53 & $0.31,0.89$ \\
\hline Ewings & 123 & 221 & 36 & 104 & 1.61 & $1.04,2.49$ \\
Rosenblatt & 253 & 215 & 500 & 488 & 1.15 & $0.92,1.43$ \\
\hline Madsen & 85 & 99 & 1 & 4 & 3.43 & $0.38,31.32$ \\
\hline Wright & 547 & 469 & 1207 & 1176 & 1.14 & $0.98,1.32$ \\
Spence & 963 & 949 & 592 & 637 & 1.09 & $0.95,1.26$ \\
\hline Nair-Shalliker & 389 & 296 & 931 & 712 & 1.01 & $0.84,1.20$ \\
\hline $\begin{array}{l}\text { Random- } \\
\text { fffects } \\
\text { summary } \\
\text { effects OR }\end{array}$ & & & & & 1.09 & $0.95-1.23$ \\
\hline Between-study & & & & & & \\
\hline
\end{tabular}

Between-study heterogeneity $\chi^{2} 12=22.92, \mathrm{P}=0.03, \mathrm{I}^{2}=43.3 \%$. CI: confidence interval; OR: odds ratio. 


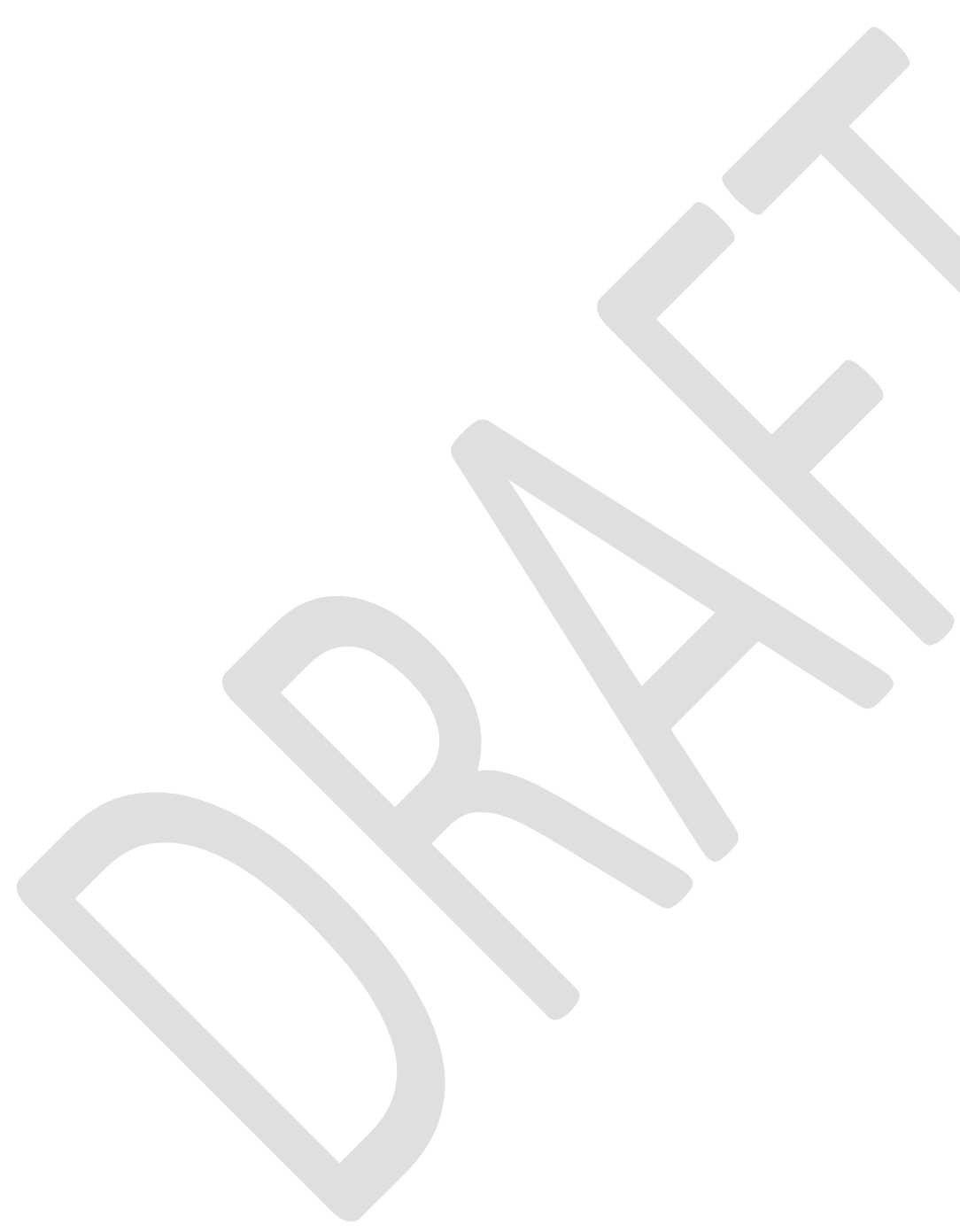

